\section{Third World development UN funds falter}

\section{Washington}

Frustrated in the United Nations by lack of progress in following up proposals from the Conference on Science and Technology for Development (UNCSTD), held in Vienna in August 1979, a group of developing countries has organized a top-level mission to try to persuade the oil-rich nations that they should be doing more to support technological efforts in the Third World.

In an initiative originating from government officials from Tunisia, Mexico, Pakistan and Guinea, a delegation made up of ministers or other top officials from ten developing countries will visit several major oil-producing countries at the beginning of next month to discuss ways of supporting technical assistance programmes. The countries to be visited include Saudi Arabia, Kuwait, the United Arab Emirates, Nigeria and Venezuela.

The delegation will then move to Paris, where it will report to the SecretaryGeneral of the Organization for Economic Co-operation and Development (OECD). Several OECD countries, in particular the Scandinavians, have already expressed enthusiastic support for the so-called "Tunis initiative", which they see as avoiding some of the road-blocks faced by classical negotiating patterns on North/ South economic issues.

Eventually it is hoped that a package can be put together in a form likely to be endorsed by the planned summit meeting between industrial and developing countries in Mexico City in October. President Ronald Reagan has recently agreed to attend the meeting (partly, it is rumoured, because President Lopez Portillo of Mexico has agreed not to invite Cuba's Fidel Castro).

The package could contain a commitment from oil-producing and developed countries to support technological development in the Third World by several hundred million dollars a year by the mid-1980s. The aim is to find a way of using the large cash surpluses being built up by the oil-producing nations to catalyse development efforts, without running into the political tensions which have polarized discussions between the Group of 77 and the industrialized nations within the United Nations.

In the event, the Interim Fund for Science and Technology, set up at the Vienna conference with an initial goal of raising $\$ 250$ million to cover two years of operation, has fallen far short of its target. Less than $\$ 60$ million has been received in pledges - and only about a third of this is thought to have been handed over. The interim fund is the responsibility of the United Nations Development Programme, and of ficials are working closely with the Tunisian government and other members of the so-called group of 10 - in addition to the four countries listed above, the other members are Peru, Senegal, Sudan, Kenya, Jordan and Sri Lanka - to find other ways of financing the projects that they have been assessing.

Although financial aid will be high on the agenda of next month's discussion with the oil-producing nations, equal emphasis is being placed on the need to support science and technology as an integral component of economic development in Third World nations. Even the oil-producing nations themselves are putting increasing emphasis on their need for technical assistance in building an economy which is not totally dependent on oil exports.

Officials from the United Nations Development Programme are also trying to link the efforts which have already been made under the interim fund to any plans emerging from the UN Conference on New and Renewable Sources of Energy, due to take place in Nairobi in August, for encouraging research on new energy sources. They argue that it would avoid

\section{Mary Lindley}

Mary Lindley, an assistant editor of Nature since 1966, died last Thursday, 7 May, after some months of illness. She was the longest-serving member of the present staff of Nature, and during her service with the journal had successively been responsible for most of the journal's separable functions. She joined the staff immediately after graduation from the University of Oxford, where she had been trained at Somerville College as a biologist with inclinations towards botany.

Mary Lindley suffered throughout her life from the consequences of restricted growth. Her method of dealing with this handicap was to behave as if it did not exist. In this spirit she learned to type, to drive a motor car, to live on her own and to travel widely. Between 1972 and 1975 she worked in the Washington office of Nature, handling the flow of scientific manuscripts through that office. When she died, Mary Lindley was the chairman of the Association for Research into

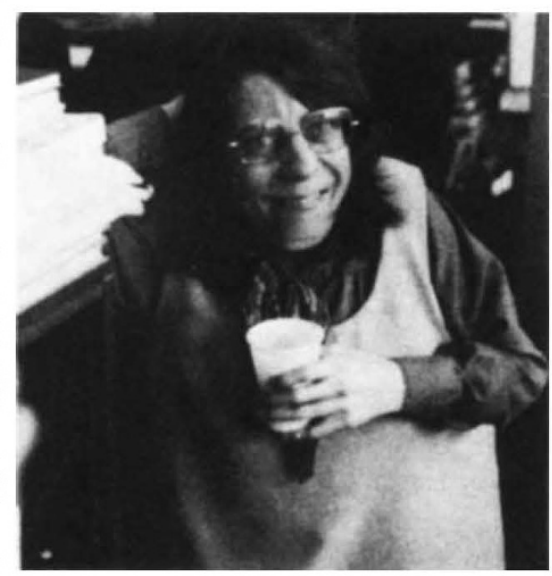

unnecessary duplication if any new research initiatives from the Nairobi conference were under the same umbrella.

A second list of projects, totalling $\$ 11.2$ million, has recently been approved for funding under the interim fund. These include $\$ 1.3$ million to Brazil aimed at improving carbon fibre technology; $\$ 500,000$ to Ethiopia for the popularization of science and technology; $\$ 670,000$ to establish a unit for research on cellulose products in the Sudan; $\$ 370,000$ for "interregional" courses in Bangladesh and Ghana on the application of modern techniques in physics to development (one on monsoon dynamics, the other on solid state physics); and $\$ 30,000$ towards a symposium in Ghana on the state of biology in Africa, being organized under the auspices of the International Council of Scientific Unions. Funding has already been offered for the initial stages of each of these projects, although whether the totals are reached depends on how many countries make good their pledges to the interim fund.

David Dickson

Restricted Growth, an organization whose formation she had helped to stimulate.

As a colleague, one of Mary Lindley's memorable attributes was her sardonic wit. Always economical with words, she could in half a sentence puncture an overblown argument - or make a joke. For much of her time on Nature, she was the chief defendant of the view that whole organisms have a place in biological studies.

She appeared to be indefatigable. To avoid the worst of the London traffic, it was until very recently her habit to set off in her tiny motor car before the rush-hour began. She would leave the office late, not only to avoid the evening rush-hour but because (she would insist) there was still work to do. Her greatest achievement was that her dealings with those whom she met in the course of her work were never compromised by her handicap; to them, she was merely a very sharp lady who happened to be small.

As an editor, Mary Lindley was the most flexible of people. In her time, she had been responsible for the Book Reviews and the News and Views sections of the journal. For more than a year before she died, she had coordinated, edited and written much of the output of the Nature-Times News Service, which appears in the London Times. A few days before she died, cheered by her release from an iron lung and apparently indifferent to the discomforts of a tracheotomy, she asked for a typewriter to be taken to St Thomas's Hospital so that she could begin to write again.

Very few knew of her mounting frustration in the past year about her deteriorating health. Her courage was, however, evident to all. 